\section{International Scientific Journal} Theoretical \& Applied Science

\author{
p-ISSN: 2308-4944 (print) e-ISSN: 2409-0085 (online) \\ Year: 2017 Issue: $11 \quad$ Volume: 55 \\ Published: $16.11 .2017 \quad$ http://T-Science.org
}

\author{
Abdinazar T. Nurmanov \\ Doctor of Science, \\ Tashkent State Pedagogical University, \\ Uzbekistan \\ anurmanovjizzax@mail.ru \\ Ulugbek A. Jabbarov \\ reseacher, \\ Tashkent State Pedagogical University, \\ Uzbekistan
}

SECTION 21. Pedagogy. Psychology.

Innovations in the field of education

\title{
ABOUT MODERN TRENDS OF PREPARATION OF TEACHERS OF ENGLISH LANGUAGE IN UZBEKISTAN (BASED ON UK EXPERIENCE)
}

Abstract: In this article we are talking about the current trends in the preparation of English teachers in the country on the basis of the UK's advanced pedagogical experience. The professional competence of the English teacher is considered in the context of integrated professionally oriented training in a foreign language, its component components are defined.

Key words: professional competence, components of professional competence, pedagogical experience of the $U K$, integrated professional foreign language competence.

Language: Russian

Citation: Nurmanov AT, Jabbarov UA (2017) ABOUT MODERN TRENDS OF PREPARATION OF TEACHERS OF ENGLISH LANGUAGE IN UZBEKISTAN (BASED ON UK EXPERIENCE). ISJ Theoretical \& Applied Science, 11 (55): 21-25.

Soi: http://s-o-i.org/1.1/TAS-11-55-4 Doi: crossef https://dx.doi.org/10.15863/TAS.2017.11.55.4

\section{О СОВРЕМЕННЫХ ТЕНДЕНЦИЯХ ПОДГОТОВКИ УЧИТЕЛЕЙ АНГЛИЙСКОГО ЯЗЫКА В УЗБЕКИСТАНЕ (НА ОСНОВЕ ОПЫТА ВЕЛИКОБРИТАНИИ)}

Аннотация: В данной статье речь идет о современных тенденияях подготовки учителей английского языка в республике на основе передового педагогического опыта Великобритании. Профессиональная компетенция учителя английского языка рассматривается в контексте интегрированной профессионально ориентированной подготовки по иностранному языку, определяется ее компонентные составляюшие.

Ключевые слова: профессиональная компетенция, компоненты профессиональной компетенции, педагогический опыт Великобритании, интегрированная профессиональная иноязычная компетентность

Введение.

Глобальные социально-экономические изменения, происходящие во всем мире, обусловили реформирование системы изучения иностранных языков как приоритетного направления дальнейшего развития высшего образования. Изучение иностранных языков, особенно английского языка как ведущего средства международного общения, межгосударственной коммуникации, является одним из главных факторов подготовки высококвалифицированных кадров на уровне международных стандартов.

В «Стратегии действий по дальнейшему развитию Республики Узбекистан в 2017-2021 годах» [1] определены приоритетные

ISPC Technological development,

Philadelphia, USA

направления работы по совершенствованию государственной молодежной политики, воспитанию интеллектуально развитого молодого поколения, кардинальному повышению качества обучения в высших образовательных учреждениях на основе внедрения международных стандартов обучения и оценки качества преподавания, углубленному изучению иностранных языков.

Сегодня высшая школа ставит задачу не только существенно обновить содержание обучения иностранным языкам, но и ввести новые способы формирования коммуникативной компетенции будущих специалистов.

В этом плане огромный интерес сегодня представляет межкультурный подход к 
обучению иностранным языкам, который получил в последнее время всеобщее признание. Развитие данного направления в образовательной парадигме современности связано во многом с появлением в мире мультикультурных сообществ, требующих от его субъектов не только знания языка, но и умения воспринимать иную культуру, взаимодействовать с ее носителями.

\section{Обзор литературы.}

Именно дисциплина «Иностранный язык» отличается высоким культурообразующим потенциалом, так как изучение иностранного языка, помимо собственно языковой подготовки и лингвистического развития, дает учащимся возможность познавать иностранную культуру в сопоставлении с родной, расширять культурологические знания и обогащать собственную духовную культуру. Это важно, так как в современной социокультурной ситуации человек находится на рубеже культур, взаимодействие с которыми требует от него диалогичности, понимания, уважения культурной идентичности других людей. Именно здесь более всего работает аксиоматическая формула лингвокультурологической концепции обучения языкам «диалог языков - диалог культур» как основа формирования полилингвальной языковой личности [9].

Применительно к подготовке учителей английского языка в педагогических вузах обращает на себя внимание тот факт, что исследования культурологической и социокультурной направленности ученых Узбекистана и СНГ связывают процесс изучения иностранного языка преимущественно с художественной культурой - литературой, живописью, архитектурой. Однако, такая важная «составляющая» профессиональной подготовки учителей английского языка как педагогическая культура, педагогический опыт страны изучаемого языка не исследовались. Между тем, знание педагогической практики и науки разных стран, изучение их опыта образования поможет решать проблемы в собственной стране, оно стимулирует осмысление и оптимальное построение отечественной педагогической системы. Имеется много оснований для взаимного обогащения педагогики разных стран в контексте глобальных мировых процессов в экономике, культуре и образовании.

Анализ изменений, происходящих в сфере образования за рубежом, и сопоставление их с теорией и практикой обновления отечественной школы дает возможность творчески использовать позитивный зарубежный опыт, что является предпосылкой повышения качества образования.
В настоящее время ввиду статуса английского языка как глобального (универсального) и его определение как такового в пределах нашего государства, на что указывают Постановления Президента И.А.Каримова [2] и государственных образовательных ведомств, наличие непосредственных международных контактов по обучению школьников и студентов за рубежом, обмена студентами между учебными заведениями США, Англии и Узбекистана, международных образовательных и научнопедагогических проектов, проблема осведомленности будущих учителей английского языка в таких областях как система образования Англии прошлого и современности, педагогика страны, особенности педагогической деонтологии является весьма актуальной.

\section{Материалы и методы.}

Профессиональная компетенция в составе интегри-рованной профессиональной иноязычной компетентности представляет собой личностную способность специалиста решать определенный класс профессиональных задач, используя знания в предметной области, представления о функциональном содержании и способах деятельности в будущей профессиональной среде, способность к осуществлению этой деятельности, восприятие себя в качестве субъекта этой среды, осознание своего места и своей миссии как части целого.

Компонентный состав профессиональной компетенции представляет собой предметнодекларативные знания, культуру профессиональной деятельности, ценностносмысловой компонент.

Предметно-декларативный компонент профессиональной компетенции специалиста определяется требованиями профессиональной среды к уровню его предметно-ориентированной подготовки к профессиональной деятельности и отражает его мотивационную и теоретикопрактическую способность к решению собственно профессиональных задач. Наряду со знаниями о стране и мире, специалист должен быть способен расширять и совершенствовать собственную картину мира, ориентироваться в медийных источниках информации (общая компетенция).

Культурно-деятельностный компонент заключается в представлении о специалисте как о субъекте культуры, носителе профессиональноэтических ценностей, способного с позиции культуры успешно функционировать в профессиональной среде, при этом развивая и совершенствуя ее и себя. Этот компонент также включает способность планировать цели, ход и результаты своей деятельности, используя свой и чужой опыт, пользоваться поисково- 
аналитическими

умениями

(когнитивная компетенция).

Ценностно-смысловой компонент - это осознание и нравственная оценка себя как субъекта профессиональной среды, своей ценности как личности, способной вносить вклад в преобразование действительности через смыслотворчество и внутреннюю гармонию. Сюда также включается и способность взаимодействовать с партнерами по общению, вступать и поддерживать контакт, владея необходимыми стратегиями (социальная компетенция) $[6,7,8]$.

Таким образом, интегрированная профессиональная иноязычная компетентность, как результат профессионально ориентированной подготовки по иностранному языку, представляет собой способность и психологическую готовность личности к продуктивному вербальному взаимодействию с окружающей ее иноязычной социальной и профессиональной средой. Компонентный состав компетентности выпускника вуза определяется областью, объектами, видами и спецификой профессиональной деятельности, и в свою очередь, является критерием отбора технологий, методов и приемов профессиональноориентированного обучения, составляющих научно-методологическую основу обучения иностранному языку в системе профессионального образования. Особый интерес для современной реформы образования, педагогической науки и практики в нашей стране представляет система обеспечения качества непрерывного педагогического образования Великобритании как одна из старейших в Европе. В течение многих лет в Великобритании не только ведутся исследования в области непрерывного педагогического образования, но и создается теоретическая и практическая база для развития этой сферы путем участия страны в различных международных проектах. Важность исследований британской системы качественной подготовки и переподготовки педагогических кадров для нашей педагогической науки и практики обусловливается тем фактом, что она первоначально функционировала в условиях ограниченного государственного финансирования, что содействовало развитию рыночных механизмов ее организации, самостоятельному поиску источников финансирования, активизации мониторинговой и маркетинговой деятельности. При неизменном сохранении национальных приоритетов, эта модель развивалась в русле общеевропейских и общемировых тенденций, решая во многом одинаковые для многих стран мира проблемы подготовки учительских кадров. В связи с этим изучение британского опыта позволит получить адекватное представление не только об общих тенденциях повышения качества подготовки учителей в мире, но и характере существующих проблем и путях их разрешения, и тем самым будет содействовать минимизированию возможных негативных последствий и ошибок, а также сопоставить собственные политические решения с практикой других, лучше оценить целесообразность и риски их принятия.

Результаты анализа структуры непрерывного педагогического образования Великобритании позволяют вывести следующую иерархию:

педагогическая профориентация и довузовская подготовка; курсы начальной подготовки учителей в школе; неуниверситетский сектор высшего образования; университетский сектор высшего образования; теоретическая и практическая подготовка стажера в течение «пробного года» в школе; последипломное образование (повышение квалификации).

Изучение обеспечения качества непрерывного педагогического образования в Великобритании приводит к выводу о том, что модель британского учителя включает в себя не только профессиональные качества, но и его профессионально-личностное развитие в контексте процесса его подготовки и переподготовки.

В связи с этим правомерно употребление понятия «современный учитель», которое стало отождествляться с понятием «учительинтеллектуал», «учитель-творец», «учительноватор», включающие в себя такие качества как: умение абстрагировать (способность нахождения новых образцов, вариантов и значений известных явлений); умение мыслить системно; умение экспериментировать (умение находить новые комбинации знаний); умение сотрудничать (обладание навыками кооперирования и взаимопомощи в поиске решений общих проблем и достижении общей цели).

$\begin{array}{ccc}\text { Анализ работ ряда } & \text { британских } \\ \text { исследователей } & \text { (М.Андервуд, } & \text { С.Бриндли, }\end{array}$
Д.Чайлд), касающихся педагогической деятельности учителей, можно выделить наиболее эффективные, по их мнению, учительские умения: умение объяснять программу понятно, на уровне учеников; умение внушать энтузиазм ученикам; умение учить пониманию, а не простому воспроизводству изученного материала; умение держаться уверенно и непринужденно; умение адекватно воспринимать происходящие события; умение быть коммуникативным и коммуникабельным; 
умение организовывать групповую работу и устанавливать положительные взаимоотношения в классе.

Целью педагогического определение повышения качества

\section{системы} образования приоритетных

британского является направлений

Как показало настоящее исследование, к концу XX столетия в Великобритании утвердились два концептуальных подхода к оценке качества профессионально-личностного развития учителя в системе непрерывного образования. Первый подход базируется на идее соответствия подготовки учителя социальному спросу, в основе которой лежит овладение учителем профессиональной компетентностью. Как показал разброс мнений по этому вопросу, данный подход демонстрирует механистический взгляд на роль учителя в британской системе образования, игнорирующий роль опыта в развитии практического применения знаний и самооценку своего труда. Второй подход предполагает оценку качества профессиональнопедагогической подго-товки и переподготовки учителя на основе концепции «практических умений и навыков», в основе которой лежит практический опыт, определяющий этапы развития в процессе перехода от положения новичка к статусу эксперта. Данный подход предполагает необходимость непрерывности процесса обучения в ходе начальной подготовки и последующем профессиональном развитии, направленном на активизацию внутреннего потенциала личности, а также совершенствование ее самомотивирующей и интеллектуальной деятельности. Тем самым, развитие способностей для оптимизации процесса обучения посредством практического опыта становится главной задачей в сфере профессионального развития.

Изучение правительственных документов, а также работ британских исследователей показало, что спецификой целей профессиональной подготовки педагогов в современной английской системе образования является предложенная ЮНЕСКО концепция «обучение через всю жизнь» (lifelong learning), которая ставит в центр всех образовательных начал человека, которому следует создать условия для полного развития его способностей на протяжении всей жизни [10, с. 235].

Существует три вида профессионального самосовершенствования английского учителя (личностное, профессиионально-теоретическое, профессионально-практическое) и три направления процесса самосовершенствования английского учителя-индивида как личности, профессионала-теоретика (широкое понятие, включающее в себя постоянное стремление к приобретению профессиональных знаний, совершенствованию умений, навыков) и учителяпрактика как организатора учебного процесса (узкое понятие, предполагающее конкретное применение приобретенных знаний на практике) [3,c.126].

К основным потребностям профессионального совершенствования английского учителя относятся:

индивидуально-личностные

(непрофессиональные); профессиональные (карьера, долгосрочные образовательные потребности); содержательные (активный запас знаний, потребность в навыках) [5].

Особого внимания заслуживает система всестороннего учета факторов карьерного становления учителя. Его продвижение к высокому уровню профессионального мастерства связывается с его личностными особенностями (историей жизни, стабильностью существования материальными и духовными потребностями), мотивами и действиями по профессиональному совершенствованию, его социализацией в педагогической среде и обществе в целом.

В настоящее время совершенствование системы профессиональной подготовки английского учителя все более связывается с возрастанием роли личности педагога, ориентированием учебно-воспитательного процесса в высшей английской педагогической школе на изменение духовных ценностей, на формирование тех качеств личности учителя, которые ему необходимы в будущей практической деятельности.

\section{Заключение.}

Таким образом, использование позитивного опыта зарубежных стран, в данном случае Великобритании, открывает новые возможности, связанные прежде всего с построением высокоэффективного процесса подготовки педагога к профессионально-личностному межкультурному взаимодействию в условиях меняющегося мира. Адаптация опыта английских колледжей и вузов педагогического направления к отечественным особенностям и условиям позволит совершенствовать процесс разработки новых технологий профессиональной подготовки, достигнуть соответствия уровню современных достижений. 


\begin{tabular}{l|lrl|l|ll} 
& ISRA (India) & $=\mathbf{1 . 3 4 4}$ & SIS (USA) & $=\mathbf{0 . 9 1 2}$ & ICV (Poland) & $=\mathbf{6 . 6 3 0}$ \\
Impact Factor: & ISI (Dubai, UAE) $=\mathbf{0 . 8 2 9}$ & PUHU (Russia) $=\mathbf{0 . 2 0 7}$ & PIF (India) & $=\mathbf{1 . 9 4 0}$ \\
& GIF (Australia) & $\mathbf{0 . 5 6 4}$ & ESJI (KZ) & $=\mathbf{3 . 8 6 0}$ & IBI (India) & $\mathbf{4 . 2 6 0}$
\end{tabular}

\section{References:}

1. (2017) Ukaz Prezidenta Respubliki Uzbekistan «O strategii deistvii po dal'neishemu razvitiyu Respubliki Uzbekistan v 2017-2021 godah» ot 7 fevralja 2017 goda № UP-4947.

2. (2012) Postanovlenie Prezidenta Respubliki Uzbekistan I. A.Karimova «O merah po dal'neishemu sovershenstvovaniyu sistemy izuchenija inostrannyh jazykov» ot 10 dekabrja 2012.

3. Bondarenko E.N. (2008) Professional'nolichnostnoe razvitie uchitelja $v$ Anglii i Finljandii na sovremennom yetape. Vestnik DGTU. Prilozhenie. - P.123-131.

4. (2009) The Bologna Process 2020 - The European Higher Education Area in the new decade- Communiqué of the Conference of European Ministers Responsible for Higher Education, Leuven and Louvain-la-Neuve, 2829 April 2009.

5. Nixon J., Martin J., Mc Keown P., Ranson S. (2005) Towards a learning profession: changing codes of occupational practice within the new management of education. //British Journal of Sociology of Education, 18, 2005. - p.5-28.

6. Nurmanov AT (2015) Technological aspects of students training to effective communication at pedagogical university. ISJ Theoretical \& Applied Science. Scranton, USA 12 (32). -p.8186.

7. Nurmanov A.T. (2011) Communicating for the future of Uzbekistan//Live \& Learn. News, views and initiatives from across the ETF community. ISSUE //20 April.-Torino, Italy. p. 18-19.

8. Nurmanov A.T. (2013). Development of communicative culture of students in the process of effective communication//The advanced Science open access journal. -United States, Torrance, ISSUE 6, June 2013. P.65-68.

9. Sa"dullaev D.S., Rahmatullaeva G.M. (2007) Mentalitet uzbekov: sociolingvisticheskii aspekt. Izvestija Akademii pedagogicheskih i social'nyh nauk, XI, M., 2007.

10. Chernecova O. V. (2013). Dvuhurovnevaja sistema vysshego pedagogicheskogo obrazovanija v sovremennoi Anglii //Modernizacija obrazovanija: teorija i praktika: materialy XX Rjazanskih pedagogicheskih chtenii, 22 marta 2013 g. Rjaz. gos. un-t im. S. A. Esenina. — Rjazan'. — p. 235-237. 